\title{
$\frac{100}{\mathrm{LuT}} \mathrm{RPES}$
}

\author{
KAROLINA PIECH*
}

\section{GRANICE OBOWIĄZKU GWARANTA WYKONUJĄCEGO ZAWÓD LEKARZA}

\section{WPROWADZENIE}

W doktrynie prawa karnego materialnego, obok licznych sporów dotyczących charakteru zaniechania i jego wpływu na odpowiedzialność karna potencjalnego sprawcy przestępstwa skutkowego, doniosłą kwestię stanowi treść obowiązku gwaranta, czyli osoby, na której ciąży prawny, szczególny obowiązek zapobiegnięcia określonemu skutkowi przestępnemu (tj. obowiązek działania w określonym przez prawo kierunku). Poświęcając wiele miejsca problematyce przyczynowości zaniechania oraz jego znaczeniu w ramach tzw. włączenia się do cudzego zakresu odpowiedzialności, znacznie rzadziej poruszano problematykę granic obowiązku gwaranta. Zagadnienie to tymczasem istotne jest ze względu na wyrażoną nie tylko na gruncie Kodeksu karnego ${ }^{1}$, lecz także Konstytucji $\mathrm{RP}^{2}$ i wiążących Polskę aktów prawnych rangi międzynarodowej ${ }^{3}$ zasadę nullum crimen sine lege. $\mathrm{Z}$ zasady tej immanentnie wynika bowiem wskazywany $\mathrm{w}$ doktrynie i orzecznictwie postulat maksymalnej określoności tworzonych typów przestępstw (nullum crimen sine lege certa), którego celem jest wyraźne rozgraniczenie typów zachowań zabronionych, potencjalnie pretendujących do roli przestępstw, oraz typów zachowań niezabronionych - czyli dozwolonych i prawnokarnie irrelewantnych ${ }^{4}$.

Pewną szczególną grupa podmiotów, występująca w roli gwaranta chyba najczęściej, są osoby wykonujące zawody medyczne, zwłaszcza zaś lekarze.

* Karolina Piech, Uniwersytet Wrocławski,

karolina.piech@uwr.edu.pl, https://orcid.org/0000-0001-8651-3998

${ }^{1}$ Ustawa z 6 czerwca 1997 r. - Kodeks karny, t.jedn.: Dz. U. 2018, poz. 1600 (dalej jako: k.k.).

${ }^{2}$ Ustawa z 2 kwietnia 1997 r. - Konstytucja Rzeczypospolitej Polskiej, Dz. U. 1997, Nr 78, poz. 483 .

${ }^{3}$ Tak np. Konwencja o ochronie praw człowieka i podstawowych wolności z 4 listopada 1950 r., Dz. U. 1993, Nr 61, poz. 284 (dalej jako: EKPC).

${ }^{4}$ Barczak-Oplustil (2013): 23. 
Wynika to ze szczególnego rodzaju relacji, jaka wiąże lekarza z pacjentem, normowanej nie tylko przez przepisy ustawy karnej, ale także przez normy zawarte w ustawach regulujących wykonywanie zawodu lekarza, oraz z wiążących lekarzy zasad deontologii zawodowej. Nie bez znaczenia są tutaj również pewne okoliczności faktyczne, a nawet oczekiwania społeczne wobec postępowania lekarzy, którym poprzeczka stawiana jest o wiele wyżej niż przeciętnej osobie, wykonującej jakikolwiek inny zawód. Zdarza się, że proponowana jest dość dyskusyjna teza, zgodnie z która na osobie wykonującej zawód lekarza obowiązki gwaranta ciążą w każdej sytuacji, w której zachodzi zagrożenie dla życia lub zdrowia drugiego człowieka.

Łatwo jednak wyobrazić sobie sytuację, w której wykonanie przez określoną osobę ciążącego na niej obowiązku gwaranta będzie pociagać za sobą narażenie dóbr prawnych tej osoby na niebezpieczeństwo, nawet w postaci możliwości wystapienia skutku śmiertelnego czy ciężkiego uszczerbku na zdrowiu. Przywołać można w tym miejscu często wskazywany w piśmiennictwie przykład relacji lekarz - pacjent zarażony wirusem HIV. Nietrudno zarysować ramy hipotetycznego zdarzenia, w którym lekarz, udając się gdzieś w celach osobistych, napotyka człowieka potrąconego przez samochód, znajdującego się w stanie zagrożenia życia i przez to wymagajacego natychmiastowej pomocy medycznej. Ów lekarz jednak nie dysponuje w danej chwili ani apteczka, ani nawet para rękawiczek lateksowych, które gwarantowałyby mu minimum bezpieczeństwa. Lekarz nie posiada również żadnych informacji o „pacjencie”nie jest w stanie stwierdzić, czy osoba ta nie jest nosicielem groźnego wirusa. Paść musi w tym miejscu pytanie: czy lekarz ma w przedstawionej powyżej sytuacji obowiązek zatamowania krwotoku, którą to czynność przecież potrafi wykonać? Innymi słowy - czy na lekarzu ciąży prawny, szczególny obowiązek działania celem zapobieżenia śmierci pacjenta? Czy też na lekarzu takim ciąży jedynie prawnokarny obowiązek udzielenia pomocy, dotyczący każdej osoby, która znalazła się w bardzo groźnej sytuacji?

Aby lepiej zrozumieć pytanie stawiane na gruncie powyższego, czysto teoretycznego, kazusu, należy dokonać bliższej analizy kilku zasadniczych kwestii. Po pierwsze - warto odnieść się do zakresu lekarskiego obowiązu udzielenia pomocy, unormowanego na gruncie ustawy o zawodzie lekarza i lekarza dentysty $^{5}$, jak również na płaszczyźnie zbioru zasad deontologii zawodowej lekarzy, którym jest Kodeks etyki lekarskiej ${ }^{6}$. Po drugie - należy zwrócić uwagę na inne normy wyrażone w ustawie karnomaterialnej, które mogą mieć wpływ na granice obowiązu gwaranta, mimo iż ustawodawca nie wskazał na to expressis verbis. Normami takimi sa przede wszystkim przewidziana na gruncie stanu wyższej konieczności zasada wyłączenia (art. 26 k.k.) oraz statuowany przez art. 162 k.k. brak obowiązku udzielenia pomocy osobie znajdującej się w położeniu grożącym bezpośrednim niebezpieczeństwem utraty życia lub

${ }^{5}$ Ustawa z 5 grudnia 1996 r. o zawodach lekarza i lekarza dentysty, t.jedn.: Dz. U. 2018, poz. 617 (dalej jako: u.o.z.l).

${ }^{6}$ Uchwała Nadzwyczajnego II Krajowego Zjazdu Lekarzy z 14 grudnia 1991 r. - Kodeks etyki lekarskiej (dalej jako: KEL). 
ciężkiego uszczerbku na zdrowiu, gdyby udzielający tej pomocy mógł narazić siebie lub inną osobę na niebezpieczeństwo utraty życia albo ciężkiego uszczerbku na zdrowiu. Co więcej, zauważyć należy, iż prawo karne zdaje się w żadnym wypadku nie wymagać od jego adresatów heroizmu w postaci narażania własnego życia na bezpośrednie niebezpieczeństwo. Tezę niniejszego artykułu stanowi zatem stwierdzenie, że ryzyko sytuacyjne modyfikuje granice obowiązku gwaranta, natomiast jego podstawowym celem jest udzielenie odpowiedzi na dwa podstawowe pytania: 1) jakie sa granice obowiązu gwaranta? 2) czy lekarz ma obowiązek podejmować działania zmierzajace do zapobieżenia skutkowi śmiertelnemu lub skutkowi w postaci uszczerbku na zdrowiu pacjenta, narażając się na niebezpieczeństwo osobiste? 3) czy na lekarzu, w sytuacji narażenia się na niebezpieczeństwo osobiste, ciąży ogólnoludzki obowiązek udzielenia pomocy, wynikający z normy zawartej w art. 162 k.k.?

\section{ZAKRES LEKARSKIEGO OBOWIĄZKU UDZIELENIA POMOCY W ŚWIETLE PRZEPISÓW USTAWY O ZAWODACH LEKARZA I LEKARZA DENTYSTY ORAZ KODEKSU ETYKI LEKARSKIEJ}

Obowiązek lekarza w zakresie udzielenia pomocy regulowany jest przede wszystkim przez przepisy u.o.z.l. Należy jednak podkreślić, iż lekarskiego obowiązku udzielenia pomocy, statuowanego przez przepisy u.o.z.l., nie należy rozumieć tożsamo z powszechnym obowiązkiem udzielenia pomocy przewidzianym w k.k. Po pierwsze, adresatem owego obowiązku jest inny zbiór podmiotów, po drugie, jego treść jest inna, po trzecie, niewypełnienie obowiązku udzielenia pomocy z k.k. pociaga za sobą realizację znamion przestępstwa formalnego (bezskutkowego), natomiast normy zawarte w u.o.z.l. nie przesadzają wcale, jakiego typu przestępstwa dopuszcza się lekarz, który zaniechał udzielenia pomocy.

Treść lekarskiego obowiązku udzielenia pomocy uregulowana jest na gruncie art. 30 u.o.z.l. W doktrynie wskazuje się, że obowiązek ten został ujęty bardzo szeroko - szerzej aniżeli na płaszczyźnie poprzednio obowiązującej ustawy. Jak podkreśla Leszek Kubicki: „Poprzednia ustawa zwalniała [...] lekarza z obowiązku udzielenia pomocy w przypadku, w którym "praktycznie możliwe jest niezwłoczne uzyskanie pomocy lekarskiej, udzielanej przez stację pogotowia ratunkowego, bądź inną instytucję przeznaczoną do udzielania pomocy lekarskiej w przypadkach nie cierpiacych zwłoki«"7. Obecnie obowiązująca ustawa stanowi natomiast, że „lekarz ma obowiązek udzielać pomocy lekarskiej w każdym przypadku, gdy zwłoka w jej udzieleniu mogłaby spowodować niebezpieczeństwo utraty życia, ciężkiego uszkodzenia ciała lub ciężkiego rozstroju zdrowia, oraz w innych przypadkach niecierpiących zwłoki"8.

\footnotetext{
7 Kubicki (2003): 4.

8 Art. 30 u.o.z.l.
} 
W doktrynie dość stanowczo podkreśla się, iż ów obowiązek nie jest zależny od źródła niebezpieczeństwa, jego charakteru czy też sposobu powstania tego niebezpieczeństwa ${ }^{9}$. Zauważyć należy przede wszystkim, że niebezpieczeństwo takie nie musi mieć (w przeciwieństwie do niebezpieczeństwa ujętego na gruncie powszechnego obowiązu udzielenia pomocy) charakteru bezpośredniego. Brak bezpośredniego charakteru owego niebezpieczeństwa dodatkowo podkreśla użycie w przepisie wyrażenia „zwłoka [...] mogłaby spowodować niebezpieczeństwo". Z takiego ujęcia wynika immanentnie, że samo niebezpieczeństwo utraty życia, ciężkiego uszkodzenia ciała lub ciężkiego rozstroju zdrowia w sytuacji, w której wymagane jest udzielenie pomocy, może być odległe od potencjalnego skutku. Jeśli zaś idzie o inne stany niecierpiące zwłoki, w których na lekarzu ciążyć będzie omawiany nakaz, to rozumieć należy je jako „każdą sytuację, która wskazuje na potrzebę interwencji lekarskiej, przy czym jest to sytuacja, w której zwłoka w udzieleniu pomocy lekarskiej mogłaby spowodować niebezpieczeństwo nastapienia skutków w przepisie tym wskazanych, bądź uwidacznia potrzebę bezzwłocznej pomocy, nawet wówczas, gdy niebezpieczeństwo nastapienia skutków, o których mowa w tym przepisie, nie jest oczywiste” ${ }^{10}$. Warto również wskazać, że „sama zwłoka w udzieleniu pomocy jest tylko jednym z elementów związku przyczynowego, występującego obok innych jeszcze, $\mathrm{z}$ tym jednak zastrzeżeniem, że taka zwłoka stanowi istotny element kauzalny" ${ }^{11}$. Innymi słowy - lekarz ma obowiązek udzielić pomocy choremu wówczas, kiedy udzielenie takiej pomocy jest bezzwłocznie potrzebne. Przypadku takiego nie będzie stanowić zatem sytuacja, w której pacjent mógłby bez zwiększenia stopnia wskazywanego niebezpieczeństwa zasięgnąć pomocy lekarskiej w innym czasie. Jak podkreśla Eleonora Zielińska, taka sytuacja w literaturze prawnomedycznej nazywana jest „nagłym wypadkiem”, „wypadkiem niecierpiącym zwłoki” lub „sytuacja urgensową"12. Wskazać należy również, że w piśmiennictwie wyróżnia się dwa rodzaje wypadku nieciepiącego zwłoki - ciężki oraz lekki, przy czym rozróżnienie to nie modyfikuje granic obowiązku udzielenia pomocy lekarskiej ${ }^{13}$.

Dokonujacc analizy obowiązku wyrażonego w art. 30 u.o.z.l., warto zadać pytanie, czy ów obowiązek jest w jakikolwiek sposób ograniczany oraz kiedy powstaje. Z literalnego brzmienia przepisu nie wynika, aby nakaz ten kiedykolwiek ulegał wyłaczeniu - ma on zatem charakter bezwzględny. Istnienia takiego obowiązku nie wyłącza również to, że z prawdopodobieństwem graniczącym z pewnością pomoc okazałaby się bezskuteczna, a wyrażony w przepisie skutek śmiertelny czy też ciężkie uszkodzenie ciała lub ciężki uszczerbek

${ }^{9}$ Filar (2000): 52.

${ }^{10}$ Kubicki (2003).

${ }^{11}$ Kubicki (2003).

12 Zielińska (2001): 350.

${ }^{13}$ Ciężki przypadek niecierpiący zwłoki dotyczy takich stanów faktycznych, w których zwłoka w udzieleniu pomocy może spowodować niebezpieczeństwo utraty życia, ciężkiego uszkodzenia ciała lub ciężkiego uszczerbku na zdrowiu, lekki przypadek niecierpiący zwłoki zaś swoim zakresem obejmuje wszelakie inne sytuacje, w których lekarz jest obowiązany do udzielenia niezwłocznej pomocy. Zatyka (2011): 24. 
na zdrowiu i tak by wystapił. Ważny jest również moment jego wystapienia. W literaturze podkreśla się, że obecność lekarza w miejscu, w którym znajduje się osoba potrzebujacca pomocy lekarskiej (tj. w bezpośrednim otoczeniu tej osoby), nie jest przesłanką niezbędną do powstania tegoż obowiązku. Lekarz może być również wezwany do udzielenia pomocy przez osobę trzecią - znajdująca się w szpitalu lub w zupełnie innym miejscu. Jak słusznie wskazuje jednak Kubicki: „Może to być wezwanie sasiedzkie, czy wezwanie do zdarzenia powstałego w pobliżu zakładu opieki zdrowotnej. Warunkiem powstania obowiązku jest jednak okoliczność, iż osoba wymagająca pomocy znajduje się w zasięgu obecności lekarza, w takiej bliskości, która umożliwia mu realne, osobiste spełnienie tego obowiązku. Kryteria oceny tych realnych możliwości, oczywiście lokalnie i środowiskowo bardzo zróżnicowanych, mają charakter obiektywny, a nie subiektywny, wyznaczany przez samego lekarza"14. Na gruncie u.o.z.l. brak jakichkolwiek norm ograniczajacych obowiązek statuowany przez art. 30 tej ustawy. W związku z tym przepis ten poddawany był częstej krytyce przez środowisko lekarskie, co znalazło wyraz w uchwale Naczelnej Rady Lekarskiej, w której przedstawiła własną propozycję brzmienia omawianego przepisu w następującej formie: „Lekarz posiadajacy prawo wykonywania zawodu jest obowiązany udzielić pomocy lekarskiej w każdym przypadku, gdy zwłoka w jej udzieleniu mogłaby spowodować niebezpieczeństwo utraty życia, ciężkiego uszkodzenia ciała lub ciężkiego rozstroju zdrowia pacjenta, a może jej udzielić bez narażania siebie lub innej osoby na niebezpieczeństwo utraty życia lub poważnego uszczerbku na zdrowiu, chyba że możliwe jest uzyskanie pomocy lekarskiej ze strony instytucji do tego powołanej" ${ }^{15}$. Proponowane brzmienie przepisu należy jednak ocenić jako zbyt dalece posunięte ograniczenie obowiązu udzielenia pomocy lekarskiej. Nietrudno bowiem wyobrazić sobie sytuację, w której każdy kontakt z pacjentem skutkować może niebezpieczeństwem utarty życia lub poważnego uszczerbku na zdrowiu, zwłaszcza że nie wskazano, iż takie niebezpieczeństwo musi mieć charakter bezpośredni, tj. mogący się natychmiast zaktualizować, bez wystapienia jakichkolwiek ogniw pośrednich. Dzieje się tak na przykład w przypadku chorób zakaźnych, których wirusy rozprzestrzeniaja się droga kropelkowa, jaką może być chociażby znana powszechnie tzw. ptasia grypa, a szczególnie COVID-19. Wprowadzenie przepisu w proponowanym przez Naczelną Radę Lekarską brzmieniu skutkować mogłoby tym, że w podobnym stanie faktycznym na żadnym z lekarzy nie ciążyłby obowiązek udzielenia pacjentowi pomocy medycznej.

Kolejnym aktem, który nakłada na lekarzy obowiązek udzielenia pomocy medycznej, jest Kodeks etyki lekarskiej. Zaznaczyć należy, że KEL ma charakter zgoła odmienny od u.o.z.l. Nie stanowi on bowiem aktu powszechnie obowiąującego, a jedynie stanowi zbiór zasad deontologii zawodowej lekarzy. Jednakże ustawa o izbach lekarskich stanowi, że lekarze i lekarze dentyści mają obowiązek przestrzegać zasad etyki zawodowej oraz podlegają odpo-

14 Kubicki (2003): 5.

15 Uchwała z 13 marca 1998 r. Naczelnej Rady Lekarskiej. 
wiedzialności zawodowej przed sądami lekarskim za postępowanie sprzeczne z normami wyrażonymi w KEL ${ }^{16}$.

Obowiązek udzielenia pomocy lekarskiej wyrażony został na gruncie art. $69 \mathrm{KEL}$, zgodnie z którym „lekarz nie może odmówić pomocy lekarskiej w przypadkach niecierpiących zwłoki, jeśli pacjent nie ma możliwości uzyskania jej ze strony instytucji powołanych do udzielania pomocy". W literaturze wskazuje się, że już samo literalne brzmienie cytowanego przepisu wskazuje na znacznie węższy zakres obowiązku udzielenia pomocy statuowanego przez KEL niż obowiązku wyrażonego na gruncie u.o.z.l. Obowiązek udzielenia pomocy lekarskiej ulega bowiem wyłączeniu, kiedy pacjent może taką pomoc uzyskać ze strony odpowiedniej instytucji. W doktrynie prawa medycznego całkiem słusznie podkreśla się, że jest to sytuacja ze wszech miar niepożądana, a nawet nieprawidłowa, obowiązek etyczny ma bowiem węższe ramy od obowiąku prawnego ${ }^{17}$. Jako że normy regulujące zasady deontologii zawodowej, jako normy bez wątpienia niższego rzędu, nie mogą ograniczać obowiązków ustawowych podmiotów będących ich adresatami, należy z całą stanowczością przychylić się do stanowiska, zgodnie z którym „ze względu na całkowita niespójność brzmienia art. 69 KEL z ustawową definicją lekarskiego obowiązku udzielenia pomocy, stracił on swoje znaczenie normatywne"18.

\section{OGRANICZENIA OBOWIAQZKU UDZIELENIA POMOCY PACJENTOWI PRZEZ LEKARZA - GWARANTA W ŚWIETLE ART. 26 § K.K. ORAZ 162 § 1 K.K.}

Zadać należy jednak pytanie, czy granice lekarskiego obowiązku udzielenia pomocy, wyznaczone nader szeroko przez przepisy u.o.z.l., moga ulec jakiemukolwiek ograniczeniu na gruncie prawnokarnym. Same przepisy u.o.z.l. bowiem nie przesądzają o prawnokarnym rodowodzie tego przepisu. Równie dobrze uznać można, że niedopełnienie obowiązu statuowanego przez art. 30 tejże ustawy może pociagać za sobą konsekwencje o charakterze cywilnoprawnym lub dyscyplinarnym. Aby udzielić odpowiedzi na postawione powyżej pytanie, należy odnieść się do norm wyrażonych na gruncie ustawy karnej, a ściślej rzecz ujmując: do norm dotyczących obowiązków gwaranta oraz do przepisów, które moga w jakiś sposób modyfikować treść tego obowiązu oraz jego granice.

Mówiąc o obowiązkach gwaranta, w pierwszej kolejności należy odnieść się do brzmienia art. 2 k.k., zgodnie z którym odpowiedzialności karnej za przestępstwo skutkowe popełnione przez zaniechanie podlega ten tylko, na kim ciążył prawny, szczególny obowiązek zapobiegnięcia skutkowi. Obowiąująca ustawa karna nie określa jednak, jakie mogą być źródła owego obowiąz-

\footnotetext{
16 Art. 8 ustawy z 2 grudnia 2009 r. o izbach lekarskich, t.jedn.: Dz. U. 2018, poz. 168.

17 Zielińska (2008): 446.

18 Reshef (2014): 90.
} 
ku. W piśmiennictwie wyrażono w tym zakresie dwa opozycyjne stanowiska. Zgodnie z pierwszym z nich (można rzec, że bardziej korzystnym dla potencjalnego sprawcy czynu zabronionego) obowiązek taki wynikać powinien z przepisów prawa powszechnie obowiązującego lub ze stosunku prawnego, jaki wiąże strony (np. pod postacia umowy cywilnoprawnej lub stosunku pracy) ${ }^{19}$.

Drugi pogląd z kolei opowiada się za przyjęciem, że potencjalne źródła obowiązku gwaranta rozumieć należy znacznie szerzej: poczynając od przepisów prawa powszechnie obowiązującego, poprzez prywatne stosunki prawne i regulacje o charakterze wewnętrznym oraz indywidualne i konkretne akty prawa administracyjnego (np. decyzje administracyjne), na sytuacji faktycznej kończąc $^{20}$. Nie wdając się w dyskusję, który z poglądów należałoby przyjąć, warto zauważyć, że w interesującym nas przypadku przyjęcie pierwszego stanowiska nie prowadziłoby niestety do jakiegokolwiek zawężenia granic obowiązku gwaranta. Zwolennicy obu poglądów wskazują bowiem, że źródłem obowiązku gwaranta jest przepis prawa powszechnie obowiąującego - a zatem również art. 30 u.o.z.l. Pogląd ten należy jednak poddać weryfikacji, albowiem omawiany akt stanowi zbiór norm regulujących zasady wykonywania określonego zawodu, nie statuuje zaś norm o charakterze prawnokarnym. Uznając zatem, że naruszenie art. 30 u.o.z.l. skutkować może głównie pociagnięciem lekarza do odpowiedzialności dyscyplinarnej, przyjać trzeba, że źródłem obowiązku gwaranta staje się określona sytuacja faktyczna, w której lekarz, wykonując określone czynności zawodowe, jest zdolny do udzielenia pacjentowi pomocy (posiada odpowiednią wiedzę, narzędzia oraz kwalifikacje).

Należy więc rozważyć, czy każda sytuacja faktyczna, w której lekarz ma możliwość udzielenia pomocy pacjentowi znajdującemu się w niebezpieczeństwie, będzie immanentnie prowadzić do nałożenia na owego lekarza prawnego, szczególnego obowiązku zapobiegnięcia skutkowi. Można rzec, że wymóg taki pociagałby za sobą nałożenie na lekarzy obowiązku zaniechania niektórych aktywności życiowych, takich jak na przykład okazyjne spożywanie napojów alkoholowych, co może prowadzić do stanu upojenia, w którym lekarz nie będzie w stanie wykonać zabiegu leczniczego w sposób zgodny z zasadami sztuki medycznej. Większość przedstawicieli doktryny jednak wskazuje, że owa sytuacja faktyczna winna wynikać albo z uprzedniego wywołania sytuacji niebezpiecznej, albo być skutkiem dobrowolnego przyjęcia na siebie zobowiązania. Takie ujęcie wydaje się słuszne, a przede wszystkim ogranicza katalog źródeł obowiązku gwaranta, eliminując z nich pewne sytuacje niespodziewane, w których ciężko byłoby oczekiwać od podmiotu swego rodzaju „gotowości” do zapobieżenia negatywnemu skutkowi. Podkreślić zatem należy, że osoba wykonująca zawód lekarza nie posiada zawsze statusu gwaranta - status ten wyznacza jej zakres obowiązków zawodowych oraz zobowiązanie, które na siebie przyjęła w związku z określoną sytuacją faktyczną.

W doktrynie prawa karnego materialnego wskazano, że lekarz, na którym ciąży prawny, szczególny obowiązek udzielenia pomocy medycznej, nie może

${ }^{19}$ Zoll (1982): 32-36.

${ }^{20}$ Spotowski (1987): 58. 
powoływać się na art. $162 \S 1 \mathrm{k} . \mathrm{k} \cdot{ }^{21}$ Przepis ten stanowi: „kto człowiekowi znajdującemu się $\mathrm{w}$ położeniu grożącym bezpośrednim niebezpieczeństwem utraty życia albo ciężkiego uszczerbku na zdrowiu nie udziela pomocy, mogąc jej udzielić bez narażenia siebie lub innej osoby na niebezpieczeństwo utraty życia albo ciężkiego uszczerbku na zdrowiu, podlega karze pozbawienia wolności do lat 3". A contrario - osoba, która w wyniku udzielania pomocy miałaby się znaleźć w niebezpieczeństwie osobistym, byłaby z takiego obowiązku zwolniona, a jej zaniechanie nie nosiłoby znamion przestępstwa (w tym przypadku przestępstwa formalnego). Niektórzy z autorów uznaja, że art. 30 u.o.z.l. stanowi lex specialis wobec art. $162 \S 1$ k.k. ${ }^{22}$ Pogląd ten jest jednak w doktrynie prawa karnego poddawany krytyce ${ }^{23}$. Interpretację taką należy jednak uznać za nieprawidłowa, albowiem oznaczałaby ona, że na lekarzu w żadnej sytuacji, w której mógłby narazić siebie na (niekoniecznie bezpośrednie) niebezpieczeństwo utraty życia lub ciężkiego uszczerbku na zdrowiu, nie ciążyłby obowiązek udzielenia pomocy. Nietrudno jednak wyobrazić sobie sytuację, w której niebezpieczeństwo takie zachodzi nawet w sterylnych warunkach szpitalnych (np. w izolatce, gdzie przebywa wymagający nagłej reanimacji pacjent zarażony groźnym wirusem).

Ponadto - co stanowi argument koronny - art. 162 k.k. ustanawia nakaz działania, którego zaniechanie pociaga za sobą realizację znamion przestępstwa formalnego. Należy bowiem zdecydowanie odróżnić sytuację, w której na lekarzu ciąży obowiązek gwaranta, a więc prawny, szczególny obowiązek zapobiegnięcia skutkowi, od obowiązku wypływającego z norm art. 162 k.k. Co prawda lekarz będzie obowiązany do udzielenia pomocy osobie znajdującej się $\mathrm{w}$ bezpośrednim niebezpieczeństwie utraty życia lub ciężkiego uszczerbku na zdrowiu, jednakże granice obowiązku podjęcia przez niego działania kształtować będą się zupełnie inaczej: w przypadku gdy na lekarzu ciążyć będzie nakaz statuowany przez art. 162 k.k., obowiązek ten nie będzie obejmować tych sytuacji, w których lekarz narażałby siebie samego na niebezpieczeństwo utraty życia lub ciężkiego uszczerbku na zdrowiu. Wskazać również należy, że - jak słusznie stwierdza Jan Kulesza - „sprawca powinien przedsięwziąć w s z y s t k i e środki, które mogą odwrócić niebezpieczeństwo. Katalog środków i sposobów pomocy kształtowany jest przy tym zarówno podmiotowo, w zależności od tego, kim jest zobowiązany (laikiem, lekarzem), jak i przedmiotowo, w zależności od wymagań sytuacji i dostępności środków zdatnych do udzielenia pomocy" ${ }^{24}$. Lekarz zatem będzie miał obowiązek podejmowania zupełnie innych działań niż osoba niewykonująca zawodu medycznego, a granice jego obowiązku będą znacznie szersze.

Ostatnią płaszczyzna, na której poszukiwać można ewentualnego ograniczenia ciążacych na lekarzu obowiązków gwaranta, jest art. 26 k.k., regulujący zasady zachowania się w tzw. stanie wyższej konieczności. Zgodnie

\footnotetext{
${ }^{21}$ Wanatowska, Kulesza (1988): 12.

22 Filar (2000): 54.

23 Konarska-Wrzosek (2018).

24 Kulesza (2008): 170.
} 
z art. $26 \S 1$ k.k. nie popełnia przestępstwa, kto działa w celu uchylenia bezpośredniego niebezpieczeństwa grożącego jakiemukolwiek dobru chronionemu prawem, jeżeli niebezpieczeństwa nie można inaczej uniknać, a dobro poświęcone przedstawia wartość niższą od dobra ratowanego. Przepis ten mógłby dotyczyć takiego stanu faktycznego, w którym - przykładowo - zagrożone jest jedynie zdrowie pacjenta (np. zaistniało niebezpieczeństwo wystapienia ciężkiego uszczerbku na zdrowiu), a w wyniku udzielenia pomocy lekarskiej mogłoby dojść do narażenia na bezpośrednie niebezpieczeństwo życia lekarza. Przykładowo, lekarz znajdujacy się w pobliżu miejsca zdarzenia, w którym człowiek został porażony prądem w wyniku zerwania się linii wysokiego napięcia, nie ma obowiązku udzielania pomocy osobie, która otoczona jest przewodami elektrycznymi. Zaktualizowanie się niebezpieczeństwa, w którym w takiej sytuacji znalazłby się lekarz, byłoby bowiem tak wysoce prawdopodobne, że lekarz nie tylko podjąłby ryzyko, a wręcz sprowadził na siebie skutek w postaci uszczerbku na zdrowiu, a nawet śmierci. W takiej sytuacji zaniechanie udzielenia pomocy pozostaje działaniem w pełni legalnym, a jego bezprawność wyłączona jest w drodze kontratypizacji.

Problem stanowić może natomiast sytuacja, w której dochodzi do kolizji dóbr o charakterze równowartościowym lub gdy zagrożone jest dobro o obiektywnie nieco mniejszej wartości. Przykładowo, zagrożone jest życie pacjenta, a podjęcie przez lekarza działania celem wykonania zabiegu leczniczego wiązać będzie się z narażeniem na niebezpieczeństwo jego życia lub zdrowia. We wspominanej sytuacji zastosowanie mógłby znaleźć art. $26 \S 2$ k.k.: „Nie popełnia przestępstwa także ten, kto, ratując dobro chronione prawem w warunkach określonych $\mathrm{w} \S 1$, poświęca dobro, które nie przedstawia wartości oczywiście wyższej od dobra ratowanego". Jego zastosowanie w przypadku lekarza będącego gwarantem wyłącza jednak § 4, zgodnie z którym przepisu tego nie stosuje się, jeżeli sprawca miał szczególny obowiązek chronienia dobra poświęcanego, nawet z narażeniem się na niebezpieczeństwo osobiste.

Czy zatem lekarz ma obowiązek narażania swojego życia i zdrowia na niebezpieczeństwo? Na pytanie to odpowiedzieć należy twierdząco. Na lekarzu ciąży wówczas obwiązek udzielenia pomocy pacjentowi, reguły poświęcania dóbr w warunkach działania w stanie wyższej konieczności wykluczają bowiem możliwość zaniechania działania przez gwaranta, kiedy zagrożone dobro prawne nie posiada wartości oczywiście wyższej od dobra, które winno być przez niego ratowane. Co więcej, istota pracy lekarzy, zwłaszcza pracujących na szpitalnych oddziałach zakaźnych, zakłada, że ryzyko takie jest immanentnie wpisane w jej charakter. Przyjęcie, że lekarz może zaniechać działania, powołując się na treść art. $26 \S 2$ k.k., paraliżowałoby niejako udzielanie pacjentom pomocy medycznej. Przy przyjęciu takiego założenia możliwa byłaby sytuacja, w której żaden z lekarzy nie zechciałby podjąć się udzielenia pomocy pacjentowi zakażonemu chorobą zakaźna, co spowodowałoby jego zgon. Warto również wspomnieć o sytuacji, że granice obowiązku gwaranta mogą również ulec modyfikacji na podstawie art. $26 \S 3$ k.k., który to ustanawia instytucję kolizji obowiązków, kiedy tylko jeden z nich może być spełniony. Odmienny pogląd wyraża jednak Jerzy Lachowski, wedle którego błędne jest założenie, 
że możliwa jest identyczna sytuacja podmiotów, w stosunku do których aktualizują się obowiązki równej wagi ${ }^{25}$.

W doktrynie prawa karnego podnosi się również wątpliwość, czy na pewno lekarz ma obowiązek udzielenia pomocy medycznej, nawet z narażeniem się na niebezpieczeństwo osobiste. Wątpliwość taka nasuwa się podczas analizy przepisów innych ustaw, w których ustawodawca expressis verbis nałożył na adresatów ich przepisów obowiązek narażenia się na niebezpieczeństwo osobiste. Taki obowiązek wskazany został wprost między innymi w ustawach: o Policji ${ }^{26}$; o Straży Granicznej ${ }^{27}$ czy też w ustawie o Straży Pożarnej ${ }^{28}$. W u.o.z.l. $\mathrm{w}$ żadnym z przepisów nakaz taki nie został expressis verbis wyrażony, nie czynią tego również przepisy KEL. Wobec tego w piśmiennictwie wyrażono następujacy pogląd: „Brak wyraźnego wskazania takiego obowiązku w ustawie o zawodach lekarza i lekarza dentysty pozwala na zgłaszanie zastrzeżeń w kwestii zaliczenia profesji lekarskiej do kategorii zawodów, których wykonywanie jest połączone z nakazem narażania własnego życia lub zdrowia" ${ }^{29}$. Należy być jednak sceptycznym wobec takiego stanowiska. Po pierwsze, ustawodawca $\mathrm{w}$ żadnym miejscu nie wyłączył obowiązku udzielenia pomocy w przypadku narażenia na niebezpieczeństwo osobiste, tak jak uczynił to w art. $162 \S 1$ k.k. Po drugie, ustanowienie takiej normy prowadzić mogłoby do wspomnianego już wyżej hipotetycznego kazusu, w którym żaden z lekarzy nie miałby obowiązku udzielenia pomocy pacjentowi choremu na chorobę zakaźna, mogąca zagrażać życiu zarażonego.

Aby rozwiązać przedstawiony powyżej problem, w doktrynie wyodrębniono cztery rodzaje ryzyka, na jakie narażony może być lekarz - gwarant zobowiązany do wykonania zabiegu leczniczego i przez to do zapobieżenia skutkowi w postaci śmierci lub uszczerbku na zdrowiu pacjenta. Pierwszym rodzajem ryzyka jest ryzyko sytuacyjne, drugim zaś - ryzyko wynikające ze stanu chorobowego pacjenta. Nie bez znaczenia jest również to, czy owo ryzyko jest ryzykiem przewidywalnym czy też nieprzewidywalnym oraz czy wynika ono z sytuacji nagłej, czy też ma charakter „planowy”"

Poczynając od ryzyka sytuacyjnego, wskazać należy, że w jego przypadku źródłem niebezpieczeństwa nie jest choroba osoby potrzebującej pomocy lekarskiej, ale wszelakie inne okoliczności, włączając w to sposób zachowania się samego pacjenta (np. w postaci zachowań agresywnych). W doktrynie prawa karnego materialnego wyrażono pogląd, że lekarz nie jest obowiązany do działania w przypadku ryzyka sytuacyjnego, które wiązałoby dla niego się z niebezpieczeństwem utraty życia lub doznaniem ciężkiego uszczerbku na zdrowiu. W przypadku ryzyka wynikającego ze stanu chorobowego pacjenta natomiast

25 Lachowski (2005): 252.

${ }^{26}$ Art. 27 ust. 1 ustawy z 6 kwietnia 1990 r. o Policji, t.jedn.: Dz. U. 2020, poz. 360.

27 Art. 33 ust. 1 ustawy z 12 października 1990 r. o Straży Granicznej, t.jedn.: Dz. U. 2020, poz. 305 .

28 Art. 30 ust. 1 ustawy z 24 sierpnia 1991 r. o Państwowej Straży Pożarnej (t.jedn.: Dz. U. 2019, poz. 1499.

29 Zatyka (2011): 108.

30 Zatyka (2011): 104. 
lekarz ma obowiązek podjęcia stosownego działania, choćby naraził się przez to na niebezpieczeństwo osobiste ${ }^{31}$. Przykładowo, Marian Filar wskazuje, że obowiązek taki wynika z samej istoty zawodu lekarza, a związane z wysokimi kwalifikacjami możliwości zastosowania metod profilaktycznych pozwalaja znacznie owo ryzyko zmniejszyć ${ }^{32}$. Zadać należy jednak pytanie, czy lekarz w każdej sytuacji ma obowiązek podjęcia czynności leczniczych, jeśli ryzyko wynika właśnie ze stanu chorobowego pacjenta. Założenie takie prowadziłoby bowiem nieuchronnie do stwierdzenia, że lekarz internista, który - wybierając się na wieczorny spacer z psem i nie zabierając ze sobą apteczki - napotka rannego człowieka, którego wygląd wręcz jednoznacznie świadczy o zachorowaniu na AIDS, miałby bezwzględny obowiązek zatamowania u niego krwotoku, nawet jeśli na dłoniach lekarz posiadałby drobne skaleczenia. Taki stan faktyczny może być bowiem rozpatrywany w sposób dwojaki. Po pierwsze, rozważyć należy hipotetyczną sytuację, w której lekarz nie ma żadnej możliwości uniknięcia kontaktu z krwią ofiary, a na jego rękach pozostaja świeże zadrapania, chociażby po uprzedniej pracy w ogrodzie. Drugim przypadkiem mogłaby być natomiast sytuacja, w której lekarz posiada możliwość zatamowania krwotoku bez narażania się na kontakt z krwią rannej osoby, na przykład używając psiej smyczy lub wierzchniej warstwy swojej odzieży. W pierwszym z rozpatrywanych przypadków należałoby wyrazić dalece idaca wątpliwość, czy na lekarzu ciąży obowiązek zatamowania krwawienia, w drugim zaś - należy stwierdzić, że ten obowiązek bez wątpienia istnieje. Lekarz bowiem ma możliwość udzielenia pomocy bez narażenia siebie na osobiste niebezpieczeństwo. Co więcej, zaznaczyć należy, że w rzeczywistości społecznej takie przypadki stanowić będą przeważającą większość sytuacji faktycznych, w jakich lekarz napotyka osobę potrzebujaca pomocy - zawsze bowiem istnieje możliwość choćby podjęcia próby zatamowania krwotoku za pomoca własnej odzieży.

Następnie, należy bliżej przyjrzeć się kolejnym czynnikom, które trzeba wziaćc pod uwagę, oceniając, czy lekarz ma obowiązek narażenia się na niebezpieczeństwo osobiste, również w postaci niebezpieczeństwa wystapienia ciężkiego uszczerbku na zdrowiu lub zagrożenia życia. Czynnikiem takim jest charakter ryzyka związany ze źródłem istniejącego niebezpieczeństwa. W doktrynie wskazano, że niebezpieczeństwo może bowiem cechować się pewnym (niekiedy dość znacznym) stopniem przewidywalności, jak również może mieć charakter nagły ${ }^{33}$.

Przewidywalność danego niebezpieczeństwa czy też możliwości zaistnienia ryzyka bardzo często wynika z rodzaju wykonywanej przez lekarza specjalizacji. Truizmem jest bowiem stwierdzenie, że chirurg jest bardziej niż przeciętna osoba (również lekarz specjalizujący się w innej dziedzinie medycyny) narażony na zarażenie wirusem HIV. Trzeba również podkreślić, że przewidywalny charakter niebezpieczeństwa nie musi wiązać się jedy-

\footnotetext{
31 Kubicki (2002): 59.

32 Filar et al. (2004): 115.

33 Zatyka (2011): 105.
} 
nie z ryzykiem wynikającym ze stanu chorobowego pacjenta. Jako przykład może służyć chociażby obowiązek działania lekarza psychiatry, który musi wejść na oddział celem zbadania pacjenta, nawet jeśli pacjenci na nim przebywający zachowują się agresywnie, wynika to bowiem z istoty wykonywanego przez niego zawodu. Klasycznym, często powoływanym w literaturze przykładem jest również kazus lekarza wojskowego, który podczas ataku zbrojnego - nie zważając na niebezpieczeństwo postrzelenia - musi zatamować krwotok u rannego żołnierza.

Jeśli natomiast jakieś niebezpieczeństwo nie jest przewidywalne z racji ciążących na lekarzu - i wynikających z wykonywanej przez niego specjalizacji - obowiązków (a zatem pociaga za sobą ryzyko o charakterze nagłym, przynajmniej z subiektywnego punktu widzenia danego lekarza), to stwierdzić należy, iż w takiej sytuacji nie powinno nakładać się na takiego lekarza obowiązków gwaranta. Po pierwsze, lekarz taki niekoniecznie musi posiadać wiedzę większą niż przeciętny człowiek z zakresu innej specjalizacji. Przykładowo, lekarz psychiatra najprawdopodobniej nie posiada specjalistycznych umiejętności, które pozwoliłyby mu na podjęcie stosownego działania oraz zminimalizowanie prawdopodobieństwa urzeczywistnienia się w negatywnym skutku niebezpieczeństwa, które groziłoby mu w określonej sytuacji. Zachodzi zatem tutaj sytuacja, w której na lekarzu ciąży obowiązek udzielenia pomocy wynikajacy z art. $162 \mathrm{k} . \mathrm{k}$.

Warto jednak rozgraniczyć stopień przewidywalności ryzyka od stopnia jego nagłego charakteru. Można bowiem wyodrębnić cztery rodzaje ryzyka: ryzyko o charakterze nagłym, a jednocześnie przewidywalnym; ryzyko nagłe i nieprzewidywalne; ryzyko nienagłe i przewidywalne oraz ryzyko nienagłe i nieprzewidywalne. Ryzykiem jednocześnie nagłym i nieprzewidywalnym może być zerwanie się linii trakcyjnej, skutkujące porażeniem lekarza pradem podczas udzielania pomocy medycznej. Ryzykiem nagłym, ale mimo to przewidywalnym, może być pojawienie się pociagu na torach podczas udzielania pokrzywdzonemu pomocy lekarskiej - każdy rozsądny człowiek posiadający minimum doświadczenia życiowego może i powinien spodziewać się pojawienia się pociagu na torach; bez wątpienia możliwość przewidywania w tym przypadku zachodzi. Ryzyko nienagłe i jednocześnie przewidywalne może stanowić sytuacja dyżurującego na oddziale lekarza, mającego pod stałą opieką pacjenta cierpiącego na zagrażająca życiu chorobę zakaźna, jak również ryzyko istniejące $\mathrm{w}$ chwili udzielania pomocy rannemu żołnierzowi na froncie podczas walk zbrojnych. I wreszcie, ryzykiem nienagłym, ale jednocześnie nieprzewidywalnym będzie możliwość zarażenia się chorobą zakaźną od wieloletniego nosiciela tejże choroby, która jednakże do tej pory nie jest znana w medycynie.

Czynnikami o wiele bardziej istotnymi niż wspomniane powyżej źródło ryzyka oraz rodzaj grożącemu lekarzowi - gwarantowi niebezpieczeństwa sa stopień prawdopodobieństwa ziszczenia się owego niebezpieczeństwa (innymi słowy stopień „oddalenia” niebezpieczeństwa od potencjalnego, grożącego gwarantowi skutku) oraz posiadania odpowiednich umiejętności lub narzędzi, aby zminimalizować ryzyko jego wystapienia. Jeżeli bowiem lekarz, nawet posiada- 
jący odpowiednie kwalifikacje, nawet jeśli ryzyko wynika ze stanu chorobowego pacjenta (a tak jest przecież w przytaczanym na początku niniejszego artykułu kazusie), z powodu braku odpowiednich narzędzi, nie jest w stanie zminimalizować ryzyka wystapienia negatywnego skutku, który godziłby w jego dobra prawne, zwłaszcza zdrowie lub życie, to nie ma on obowiązku udzielenia pomocy lekarskiej pacjentowi znajdującemu w bezpośrednim niebezpieczeństwie utraty życia lub wystapienia ciężkiego uszczerbku na zdrowiu.

Reasumując, stwierdzić należy, że do nałożenia na lekarza obowiązków gwaranta nie dochodzi, jeżeli - po pierwsze - stopień prawdopodobieństwa ryzyka wystapienia negatywnego dla życia/ zdrowia gwaranta skutku jest wysoki. Podkreślić trzeba, że to właśnie wysoki stopień ryzyka jest warunkiem niezbędnym dla wyłączenia obowiązku zapobiegnięcia skutkowi. Samo źródło ryzyka nie jest ani wystarczające, ani konieczne do wyłączenia nakazu działania. Po drugie - niezmiernie istotne jest, czy lekarz posiada odpowiednie (związane z wykonywanym zawodem) umiejętności oraz narzędzia niezbędne do zminimalizowania owego skutku. Jeżeli zbiegną się ze sobą dwa czynniki wysoki stopień prawdopodobieństwa ziszczenia się ryzyka oraz niemożność zmniejszenia owego stopnia - należy rozważyć możliwość wyłączenia ciążącego na lekarzu obowiązku udzielenia pomocy medycznej.

Zbliżając się do końca niniejszych rozważań, warto również wspomnieć, że zakres obowiązku gwaranta można postrzegać w dwóch aspektach - zarówno w aspekcie formalnym, jak i w aspekcie materialnym ${ }^{34}$. Jak wskazano w literaturze, ,aspekt formalny polega na określeniu zakresu ochrony, jaka zobowiązany jest roztoczyć nad określonymi dobrami dany podmiot. Zakres ten może obejmować pieczę określonego dobra przed wszelkim grożącym mu niebezpieczeństwem albo obowiązek nadzoru potencjalnego źródła zagrożenia tak, aby nie wywołało ono niebezpieczeństwa"35. Zakres obowiązku lekarza - gwaranta w aspekcie formalnym ująć można zwięźle w sposób następujący: na lekarzu ciąży prawny, szczególny obowiązek zapobiegnięcia skutkowi śmiertelnemu lub ciężkiemu uszczerbkowi na zdrowiu pacjenta, o ile ów skutek stanowiłby urzeczywistnienie się niebezpieczeństwa związanego z określoną jednostką choroba, a wynikajace ze stanu chorobowego pacjenta ryzyko grożące lekarzowi nie cechuje się wysokim prawdopodobieństwem ziszczenia się negatywnego skutku lub istniejące wysokie ryzyko można zminimalizować, wykorzystując odpowiednie narzędzia oraz posiadane przez lekarza kwalifikacje. Absurdem byłoby bowiem wymaganie od lekarza pieczy nad tymi dobrami w ogólności, kiedy niebezpieczeństwo pochodziłoby z innych źródeł (np. z bezprawnego działania osoby trzeciej), oraz oczekiwanie zachowań heroicznych, które nazwać wręcz można „rozwleczonym w czasie aktem samobójstwa”.

${ }^{34}$ Aspekt materialny zaś dotyczy dokładnego określenia, jakie działania winien był podjąć gwarant, aby spełnić ciążący na nim obowiązek.

${ }^{35}$ Tokarczyk (2014): 206. 


\section{ZAKOŃCZENIE}

Granice ciążącego na lekarzu obowiązku gwaranta, statuowanego przede wszystkim przez normy art. 30 u.o.z.l., jak również - po części - przez przepisy KEL, zostały uregulowane bardzo szeroko. Nie można jednak zgodzić się z przyjmowanym niekiedy $\mathrm{w}$ piśmiennictwie karnistycznym poglądem, wyrażanym między innymi przez Leszka Kubickiego ${ }^{36}$ oraz Marię Boratyńską i Przemysława Konieczniaka ${ }^{37}$, wedle którego sam art. 30 u.o.z.l. stanowi wystarczająca podstawę do stwierdzenia, że na każdym lekarzu ciąży prawny, szczególny obowiązek zapobieżenia skutkowi w postaci śmierci lub ciężkiego uszczerbku na zdrowiu człowieka. Stanowisko to uznać należy za zbyt dalece posunięte. Poszukując bowiem źródeł prawnego, szczególnego obowiązku będącego lekarzem gwaranta, można wskazać na - co prawda nieliczne, ale jednak istniejące - wyłączenia, które limituja granice tego obowiązku. Przychylić należy się zatem do poglądu wyrażanego na przykład przez Andrzeja Zolla, zgodnie którym art. 30 u.o.z.l. stanowi źródło „ogólnego, zawodowego obowiązku lekarza", a nie źródło obowiązku gwaranta, który na gruncie prawnokarnym może podlegać różnorakim ograniczeniom. Trzeba również stwierdzić, że w przypadku naruszenia omawianego przepisu lekarz może podlegać nie tylko odpowiedzialności karnej, ale także odpowiedzialności cywilnoprawnej lub dyscyplinarnej, a żadne użyte przez ustawodawcę sformułowanie nie wskazuje, aby przepis ten miał charakter prawnokarny.

Oceniając możliwość wyłączenia odpowiedzialności karnej lekarza - gwaranta, który zaniechał działania zmierzającego ku zapobieżeniu skutkowi w postaci śmierci lub ciężkiego uszczerbku na zdrowiu pacjenta, przy czym przyczyną owego zaniechania było grożące lekarzowi niebezpieczeństwo osobiste (np. bezpośrednie niebezpieczeństwo utraty życia), należy zadać pytanie, jak bardzo owo niebezpieczeństwo oddalone było od skutku. Innymi słowy, jaki charakter miało ryzyko: czy było ono wysokie oraz czy istniała możliwość zminimalizowania owego ryzyka, głównie przez użycie właściwych narzędzi? Odrzucić należy natomiast często wyrażany w doktrynie prawa karnego materialnego pogląd, że jedynie sytuacyjny charakter ryzyka wiąże się z możliwością wyłączenia obowiązku udzielenia pomocy lekarskiej, a w żadnym wypadku - ryzyko, którego źródłem jest stan chorobowy pacjenta. Przechodząc na grunt przedstawianego na początku niniejszego artykułu kazusu, stwierdzić należy, że w prezentowanych okolicznościach lekarz, który znajduje się w sytuacji niezwiązanej z jego życiem zawodowym oraz nie posiada żadnych środków, które mogłyby zapewnić mu ochronę przed zarażeniem wirusem HIV, nie ma obowiązku zapobieżenia możliwemu skutkowi śmiertelnemu, będącemu wynikiem bezpośredniego niebezpieczeństwa utraty życia z powodu znacznej utraty krwi przez przypadkowo napotkaną osobę.

\footnotetext{
${ }^{36}$ Kubicki (2003).

37 Boratyńska, Konieczniak (2001): 198.
} 
Barczak-Oplustil, A. (2013). Obowiązywanie zasady nullum crimen sine lege. Wybrane problemy. Czasopismo Prawa Karnego i Nauk Penalnych 3: 5-22.

Boratyńska M., Konieczniak, P. (2001). Prawa pacjenta. Warszawa

Filar, M., Krześ, S., Marszałkowska-Krześ, E., Zaborowski, P. (2004). Odpowiedzialność lekarzy i zakładów opieki zdrowotnej. Warszawa

Filar, M. (2000), Lekarskie prawo karne. Kraków.

Konarska-Wrzosek, V. Komentarz do art. 162 k.k. Warszawa: Lex/el.

Kubicki, L. (2002). Obowiązek udzielenia pomocy lekarskiej. Warszawa.

Kubicki, L. (2003). Obowiązek udzielenia pomocy lekarskiej. Prawo i Medycyna 13: 6-19.

Kulesza, J. (2008). Przestępstwo nieudzielenia pomocy w niebezpieczeństwie. Czasopismo Prawa Karnego i Nauk Penalnych 2: 163-180.

Kulesza, W., Wanatowska, W. (1988). Odpowiedzialność prawna lekarza. Warszawa.

Lachowski, J. (2005). Stan wyższej konieczności w polskim prawie karnym. Warszawa.

Reshef, M. (2014). Lekarz a społeczeństwo. Komentarz do V rozdziału Kodeksu etyki lekarskiej. Medycyna Współczesna 6: 85-100.

Spotowski, A. (1987), Kilka uwag o obowiązku gwaranta w prawie karnym. Państwo i Prawo 42(11): $164-178$.

Tokarczyk, D. (2014). Obowiązek gwaranta w prawie karnym. Ruch Prawniczy, Ekonomiczny i Socjologiczny 76(4): 203-214.

Zatyka, E. (2011). Lekarski obowiązek udzielenia pomocy. Warszawa.

Zielińska, E. (2001). Odpowiedzialność zawodowa lekarza i jej stosunek do odpowiedzialności karnej. Wybrane zagadnienia. Warszawa.

Zielińska, E. (2008). Ustawa o zawodach lekarza i lekarza dentysty. Komentarz. Warszawa.

Zoll, A. (1982). Okoliczności wyłączające bezprawność czynu. Warszawa.

\section{LIMITS OF THE OBLIGATION OF A GUARANTOR PERFORMING A MEDICAL PROFESSION}

\section{Sum mary}

The article deals with the issue of the limits of the obligation of the guarantor, i.e. the person who is under a specific legal obligation to prevent a criminal effect, on the basis of substantive criminal law. The author considers whether the limits of this obligation are in any way limited with regard to a person performing the profession of a doctor. For this purpose, she analyses the provisions of the Act on the Professions of a Doctor and Dentist and the Code of Medical Ethics and the provisions of the Penal Code. Then, referring to the achievements of the criminal law doctrine, she distinguishes particular types of risk. The article ends by providing an answer to the question of whether the doctor is obliged to save the health or life of the patient if this involves exposure to personal danger.

Keywords: guarantor; doctor; patient; personal danger 
